\title{
LVIII. On Mr. Talbot's proposed method of ascertaining the greatest depth of the ocean
}

\section{T. R. F}

To cite this article: T. R. F (1833) LVIII. On Mr. Talbot's proposed method of ascertaining the greatest depth of the ocean, Philosophical Magazine Series 3, 3:17, 352-353, DOI: 10.1080/14786443308648199

To link to this article: http://dx.doi.org/10.1080/14786443308648199

册 Published online: 01 Jun 2009.

Submit your article to this journal $₫$

Џ Article views: 2

Q View related articles $₫$ 
352 On Mr. Talbot's Proposed Method of sounding the Ocean.

extremity of the abdomen, $\frac{1}{5}$ th of an inch ; length of the cephalothorax $\frac{1}{10}$; breadth $\frac{1}{13}$; breadth of the abdomen $\frac{1}{12}$; length of a posterior leg $\frac{2}{5}$; length of a leg of the third pair $\frac{1}{4}$.

This species, which appears to have a closer affinity with the Agelena than with the spiders of any other genus, occurs in the woods at Oakland; it is found occasionally under stones, but is by no means common. I am at present ignorant of its œconomy, and the male has not yet fallen under my observation.

Oakland, Denbighshire, Sept. 30, 1833.

LVIII. On Mr. Talbot's Proposed Method of ascertaining the. greatest Depth of the Ocean.

To the Editors of the Philosophical Magazine and Journal. Gentlemen,

HAVING been absent from England, your Number for August last has only just come to hand, which will account for the delay of my present notice of one of Mr. H. F. Talbot's proposed experiments. My object in sending the following remarks is for the purpose of inducing any person who may be inclined to try his second experiment, to pause before they commence such a trial as he proposes. I admit, with Mr. Talbot, that it would be very desirable, if possible, to reduce the problem respecting the greatest depth of the ocean to the test of actual experiment; but I must most decidedly object to his proposed method. The primâ facie part of his principle is, that there must be ground, (a point that is not admitted by every one,) or his shell will never explode: but without mooting this point, if there is any credit to be placed on Mi. Perkins's experiments, (and I believe no one doubts them,) Mr. Talbot's shell would float long before it could reach the bottom, as it is now pretty well ascertained that at a certain depth the sea is specifically heavier than any body which we are acquainted with, consequently a cast-iron shell could not penetrate it.

As to the danger of the experiment, there could be none; for supposing it did reach the bottom and exploded, it should be borne in mind that miners and others who have occasion to blast rocks under water, find that about 3 or 4 fathoms is quite sufficient to protect them from any injury.

Again, supposing that the experiment could be tried as Mr. Talbot proposes, it seems to have escaped his recollection that no body, in a moving current of water, can fall perpendicularly; and also that at certain depths there are various currents running, all which would tend to give erroneous results. 
Mr. Faraday's Experimental Researches in Electricity. 353

With respect to the explosion of the shell being audible at a great depth, the experiment at Geneva is not any proof; for if I recollect aright, that was superficial sound, not perpendicular sound, - a difference of considerable consequence.

Palace Yard, Sept. 23, 1833.

T. R. F.

LIX. Experimental Researches in Electricity.-Third Series. By Michaed Faraday, D.C.L. F.R.S. M.R.I. Fullerian Prof. Chem. Royal Institution, Corr. Mem. Royal Acad. of Sciences, Paris, Petersburgh, \&c.\&c.

[Concluded from p. 262.]

\section{Magneto-Electricity.}

343. Tension. - THE attractions and repulsions due to the tension of electricity have been well observed with that evolved by magneto-electric induction. $M$. Pixii, by using an apparatus, clever in its construction and powerful in its action*, was able to obtain great divergence of the gold leaves of an electrometer + .

344. In motion: i. Evolution of Heat.-The current produced by magneto-electric induction, can heat a wire in the manner of ordinary electricity. At the British Association of Science at Oxford, in June of the present year, I had the pleasure, in conjunction with Mr. Harris, Professor Daniell, Mr. Duncan, and others, of making an experiment, for which the great magnet in the museum, Mr. Harris's new electrometer (287.), and the magneto-electric coil described in my first paper (34.), were put in requisition. The latter had been modified in the manner I have elsewhere described $\ddagger$, so as to produce an electric spark when its contact with the magnet was made or broken. The terminations of the spiral, adjusted so as to have their contact with each other broken when the spark was to pass, were connected with the wire in the electrometer, and it was found that each time the magnetic contact was made and broken, expansion of the air within the instrument occurred, indicating an increase, at the moment, of the temperature of the wire.

345. ii. Magnetism. - These currents were discovered by their magnetic power.

346. iif. Chemical Decomposition.-I have made many endeavours to effect chemical decomposition by magneto-electri-

+ Annales de Chimie, I. p. 322.

$\ddagger$ Phil. Mag. and Annals, N.S. 1832, vol. xi. p. 405 .

Third Series. Vol. 3. No. 17. Nov. 1833. 